\title{
Antimicrobial efficacy of silver nanoparticles in transparent wood coatings
}

\author{
Tina Künniger $\cdot$ Markus Heeb $\cdot$ Martin Arnold
}

Received: 4 November 2013/Published online: 12 January 2014

(C) Springer-Verlag Berlin Heidelberg 2014

\begin{abstract}
Results on the antimicrobial efficacy of silver nanoparticles in transparent wood coatings for outdoor application are presented. The performance of different hydrophobic, transparent coating systems with and without silver was studied during 2 years of natural weathering. In addition, laboratory efficacy tests were carried out on nonweathered and weathered specimens to assess the resistance of the coatings against mold, blue stain and algae. The protective effect of the tested silver containing coatings against common microorganisms was insufficient, even under initial, non-weathered conditions. Reasons for the failure are the inadequate initial silver concentrations below $50 \mathrm{ppm}$ in the coatings and the associated insufficient availability of free silver ions on the coating surface.
\end{abstract}

\section{Antimikrobielle Wirkung von Nanosilberpartikeln in transparenten Holzbeschichtungen}

\section{Introduction}

The trend to increase the energy efficiency of buildings by using thick thermal insulation layers results in colder external surfaces and consequently enhances moisture condensation on the outer building envelope. Therefore, the demand for functional coatings to avoid growth of microorganisms is increasing. On the other hand, there is a general environmental discussion about organic biocides

T. Künniger $(\bowtie) \cdot$ M. Heeb $\cdot$ M. Arnold Applied Wood Materials Laboratory, Empa, Swiss Federal Laboratories for Materials Testing and Research, Ueberlandstrasse 129, 8600 Düebendorf, Switzerland e-mail: tina.kuenniger@empa.ch and the intention to reduce their use in coating products. Based on its strong toxicity among a wide range of microorganisms combined with low toxicity to humans, silver appears to be a possible alternative. While many reports on the effectiveness of silver against bacteria are available (Fabrega et al. 2011; Marambio-Jones and Hoek 2010; Musee et al. 2011), information about the protective effect of silver in wood façade coatings especially against mold and blue stain are rare (Plaschkies et al. 2010). Data about experiences during natural weathering are completely missing.

To extend the knowledge in this respect, the functionality and the safety of silver nanoparticle (Ag-NP) containing, hydrophobic and transparent coating systems for outdoor applications on wooden façade elements was investigated, and the results were compared with biocide free and organic biocide containing coatings. The results regarding functionality are presented and discussed in this Brief Original.

More detailed information about the project is given in Künniger et al. (2011). Additional comprehensive information on the environmental impact, especially the loss of active substances (silver and organic biocides) during weathering into the runoff water and their toxicity to different water organisms are published in Künniger et al. (2014).

\section{Materials and methods}

Laboratory scale façade elements (horizontal planking) with an area of $0.75 \times 1.44 \mathrm{~m}^{2}$ and $0.63 \times 0.35 \mathrm{~m}^{2}$, respectively, were produced from industrially manufactured lamellas made of Norway spruce (Picea abies). Five different water-based, transparent and hydrophobic coating 
Table 1 Coating systems and properties

Tab. 1 Beschichtungssysteme und deren Eigenschaften

\begin{tabular}{|c|c|c|c|c|c|}
\hline & HySiwAg & HySi & OARwAg & AARwB & $\mathrm{ARwB}$ \\
\hline Type & Hydrolysed Silane & $\begin{array}{l}\text { Hydrolysed } \\
\text { Silane }\end{array}$ & $\begin{array}{l}\text { Oily Alkyd } \\
\text { Resin }\end{array}$ & Alkyd/Acryl Resin & Alkyd Resin \\
\hline Biocide & $\begin{array}{l}\text { Ag-NP }(\varnothing 10-30 \mathrm{~nm}) \\
46 \mathrm{ppm}\end{array}$ & None & Silver 2 ppm & $\begin{array}{l}\text { Propiconazole } 2.28 \\
\text { w } \% \text { IPBC } 0.18 \mathrm{w} \%\end{array}$ & $\begin{array}{l}\text { IPBC, DCOIT and } \\
\text { OIT all }<1.25 \mathrm{w} \%\end{array}$ \\
\hline Film forming & No & No & Yes $\sim 40 \mu \mathrm{m}$ & Yes $\sim 50 \mu \mathrm{m}$ & Yes $\sim 100 \mu \mathrm{m}$ \\
\hline $\begin{array}{l}\text { Contact angle with } \\
\text { water }\end{array}$ & $\sim 138^{\circ}$ & $\sim 141^{\circ}$ & $\sim 94^{\circ}$ & $\sim 103^{\circ}$ & $\sim 98^{\circ}$ \\
\hline
\end{tabular}

systems (Table 1) were selected and applied according to the manufacturer recommendations. All five products were commercially available and, except for $\mathrm{HySi}$, labeled as antimicrobial. As a benchmark, additional reference elements without surface treatments were produced. The endgrain surfaces of the lamellas were sealed with a $2 \mathrm{P}-\mathrm{PU}$ paint to avoid fungal growth starting from the end-grain.

\subsection{Natural and artificial weathering}

The façade elements were installed vertically on metal racks at Empa premises and exposed to SW (220 $)$ direction from June 2009 to June 2011.

The large façade elements were observed regarding the overall performance of the coatings, especially their resistance to growth of microorganisms. All façade elements were visually examined at regular intervals during the time of natural weathering.

The smaller façade elements were removed after 2 months for subsequent laboratory efficacy tests.

Artificial weathering included four cycles. Each cycle consisted of $3 \mathrm{~h}$ radiation and $40{ }^{\circ} \mathrm{C}$ surface temperature, followed by $0.5 \mathrm{~h}$ sprinkling with around 401 water and finally $2.5 \mathrm{~h}$ conditioning at $20{ }^{\circ} \mathrm{C}$ and air dehumidifying. The radiation in the weathering chamber was performed using 20 daylight bulbs 'Ultra Vitalux' (bulb specification: $13.6 \mathrm{~W} / \mathrm{h}$ UVA $315-400 \mathrm{~nm}$ and $3.0 \mathrm{~W} / \mathrm{h}$ UVB 280-315 nm) for $3 \mathrm{~m}^{2}$ façade. The artificially weathered lamellas were used for laboratory efficacy tests.

\subsection{Laboratory efficacy tests}

The laboratory efficacy tests were carried out with mold (Internal SOP 004‘349), blue stain (EN 152:1988) and algae (Internal SOP 004‘350) cultures on new specimens, 2 months naturally weathered specimens and artificially weathered specimens of all coatings except for ARwB. With ARwB, only new specimens and specimens after artificial weathering were tested. In each case, six specimens with dimensions of $40 \times 40 \times 10 \mathrm{~mm}^{3}$ were tested for mold and algae, respectively, and for blue stain with dimensions $90 \times 40 \times 10 \mathrm{~mm}^{3}$.

After weathering but before efficacy tests, all specimens were stored for 2 weeks under controlled climate conditions $\left(20^{\circ} \mathrm{C}, 65 \% \mathrm{RH}\right)$, then sterilized with ethylene oxide for $1 \mathrm{~h}$ under vacuum $\left(0.65 \mathrm{bar}, 55^{\circ} \mathrm{C}\right)$ and finally placed in incubation vessels on Vermisol ${ }^{\circledR}$ Vermiculit. The pretreated specimens were inoculated with the microorganisms and incubated for 6 weeks $\left(22^{\circ} \mathrm{C}, 70 \% \mathrm{RH}\right)$ for mold and blue stain, respectively, and 12 weeks (room temperature and diffuse daylight) for algae. The rating factors are listed in Table 2. At the same time, growth and activity specimens were run additionally to control the vitality of the used microorganisms. More detailed information is given in Künniger et al. (2011).

\section{Results and discussion}

During the first year of natural weathering, only 8-24 1/m rainwater, depending on the hydrophobic character of the coating, run over the coated surfaces of the façade elements. However, especially in spring and autumn, condensation also led to moisturisation of the façade promoting fungi and algae growth.

Already after 1 year, the OARwAg and HySi coatings as well as the untreated spruce specimens were affected by microorganisms, while the other coatings were still intact. The affection by microorganisms was delayed on the silane based coatings compared to uncoated spruce during outdoor weathering. It can be assumed that this effect was rather induced by the hydrophobicity of the coating and/or the silane components than by the Ag content, because the non-Ag formulation showed almost the same performance.

After 2 years of natural weathering, only the coatings with organic biocides (AARwB and ARwB) still remained unaffected. The silane based coatings with and without silver (HySiwAg and HySi) showed no difference and were comparable to the untreated spruce after 1 year of weathering. 
Table 2 Efficacy tests; rating of non-weathered and weathered specimens

Tab. 2 Wirksamkeitstests; Bewertung von unbewitterten und bewitterten Proben

\begin{tabular}{|c|c|c|c|}
\hline & Non-weathered & $\begin{array}{l}2 \text { months natural } \\
\text { weathering }\end{array}$ & $\begin{array}{l}\text { Artificial } \\
\text { weathering }\end{array}$ \\
\hline \multicolumn{4}{|l|}{ Spruce $^{\mathrm{a}}$} \\
\hline Mold & 4 & n.t. & n.t. \\
\hline Blue stain & 3 & n.t. & n.t. \\
\hline Algae & 3 & n.t. & n.t. \\
\hline \multicolumn{4}{|l|}{ HySiwAg } \\
\hline Mold & 3.5 & 4.75 & 2.5 \\
\hline Blue stain & 2.5 & 3.0 & 2.5 \\
\hline Algae & 2.75 & 2.5 & 3.5 \\
\hline \multicolumn{4}{|l|}{ HySi } \\
\hline Mold & 4.5 & 5.0 & 4.0 \\
\hline Blue stain & 2.5 & 3.0 & 2.5 \\
\hline Algae & 2.5 & 2.5 & 2.75 \\
\hline \multicolumn{4}{|l|}{ OARwAg } \\
\hline Mold & 4.5 & 4.5 & 4.5 \\
\hline Blue stain & 2.5 & 3.0 & 2.5 \\
\hline Algae & 2.75 & 2.5 & 2.0 \\
\hline \multicolumn{4}{|l|}{ AARwB } \\
\hline Mold & 0.0 & 0.5 & 0.5 \\
\hline Blue stain & 0.0 & 0.0 & 0.0 \\
\hline Algae & 0.0 & 1.5 & 0.0 \\
\hline \multicolumn{4}{|l|}{$\mathrm{ARwB}$} \\
\hline Mold & 0.0 & n.t. & 0.0 \\
\hline Blue stain & 0.0 & n.t. & 0.0 \\
\hline Algae & 0.0 & n.t. & 0.0 \\
\hline
\end{tabular}

Rating factors: Mold and algae: 0 Not affected, 1 Visible under microscope only, 2 Visible, $\leq 25 \% * *, 3$ Visible, $\leq 50 \% * *, 4$ Visible, $>50 \% * *, 5$ Visible, $100 \% * *$

Blue stain: 0 Not affected, 1 Minor affected (max. 10 spots**, $<2 \mathrm{~mm}$ ), 2 Visible, $\leq 50 \% * *, 3$ Visible, $>50 \% * *$

** Affected percentage of the tested specimen surface

${ }^{\text {a }}$ Untreated

Beside the low silver content in the coatings OARwAg and HySiwAg, there were some other reasons for the insufficient durability. The OARwAg coating showed a generally bad performance, also induced by insufficient UV protection. The early damaged coating could not protect the wood against moisture and established thereby a good basis for microorganism colonization. The silane based coating (HySiwAg) did not protect the wood substrate against air humidity and UV light. The UV degradation of the wood substrate underneath the coating led to a loss of the coating after a short time period. High wood moisture was a consequence and again the basis for microorganisms to grow.

Laboratory efficacy tests confirmed the observation results made on specimens during natural weathering. Only the two organic biocide containing coatings (AARwB and ARwB) showed sufficient protection against the tested microorganisms (Table 2).

The laboratory test clearly showed that a silver concentration below $50 \mathrm{ppm}$ is not sufficient to protect the coating surface against microorganisms. Obviously, there are not enough silver ions freely available on the coating surface, which are necessary for an efficacy against fungi and algae. Free silver ions tend to react quickly with sulfur and/or chlorine compounds of the environment and are therefore no more effective against microorganisms. It has not yet been proven, whether a high initial silver content could overcome this problem.

\section{Conclusion}

The results of the study showed that under the tested conditions the silver containing commercial coatings did not protect a wooden façade against microorganisms such as mold, blue stain and algae. One reason for this result might have been the low initial silver concentration below $50 \mathrm{ppm}$ in the coating.

A slightly delayed growth of microorganisms on the silane based coatings during natural weathering was rather induced by the hydrophobic character of the surface due to the silane components than by the silver content.

Acknowledgments Financial support of the Federal Office for the Environment (BAFU) and the 'Fonds zur Förderung der Wald-und Holzforschung' (WHFF) is gratefully acknowledged.

\section{References}

Empa internal SOP 004‘349 (11.06.2002) Prüfung von Anstrichen und Putzen: Verhalten gegenüber Pilzen

Empa internal SOP 004‘350 (11.06.2002) Prüfung von Anstrichen und Putzen: Verhalten gegenüber Algen

EN 152 Teil 1 (1988) Laboratoriumsverfahren zur Bestimmung der vorbeugenden Wirksamkeit einer Schutzbehandlung auf verarbeitetem Holz gegen Bläuepilze

Fabrega J, Luoma SN, Tyler CR, Galloway TS, Lead JR (2011) Silver nanoparticles: behaviour and effects in the aquatic environment. Environ Int 37:517-531

Künniger T, Huch A, Heeb M, Gerecke A, Ulrich A, Vonbank R, Kunz P (2011) Freisetzung von nanoskaligen und konventionellen Bioziden aus beschichteten Holzfassaden während der Bewitterung: Auswaschung und deren Folgen auf die Funktionalität der Beschichtung. Wiss. Schlussbericht, Empa Dübendorf

Künniger T, Gerecke AC, Ulrich A, Huch A, Vonbank R, Heeb M, Wichser A, Haag R, Kunz P, Faller M (2014) Release and environmental impact of silver nanoparticles and conventional organic biocides from coated wooden façades. Environ Pollut 184:464-471

Marambio-Jones C, Hoek EMV (2010) A review of the antibacterial effects of silver nanomaterials and potential implications 
for human health and the environment. J Nanopart Res 12: $1531-1551$

Musee N, Thwala M, Nota N (2011) The antibacterial effects of engineered nanomaterials: implications for wastewater treatment plants. J Environ Monit 13:1164-1183
Plaschkies K, Jacobs K, Scheiding W, Schmid H (2010) Alternative Wirkstoffe für Holzschutzmittel. Holz-Zentralblatt 2010: 376-377 